\title{
Urethral cancer managed with phallus preserving surgery: a case report
}

\author{
Emily Walsh ${ }^{1 *}$, Niall Kelly ${ }^{1}$, Padraig Daly ${ }^{1}$, Nigam Shah ${ }^{2}$ and Ivor Cullen ${ }^{1}$
}

\begin{abstract}
Background: Primary urethral carcinoma (PUC) is rare and accounts for $<1 \%$ of all genito-urinary cancers. There is a male predominance of 3:1 and a peak incidence in the 7th and 8th decades. The aetiology of this cancer is similar to penile cancer, and the human papilloma virus (HPV) is thought to be an essential factor in tumorigenesis. Urethral cancer should be diagnosed and staged with a combination of tumour biopsy, MRI, and CT with treatment involving a multimodal approach. Contemporary management emphasises phallus-preserving surgery where feasible.

Case presentation: Here, we describe a case of distal urethral carcinoma, which presented as a metastatic groin mass and identifying the primary lesion proved challenging. Diagnostic flexible cystoscopy identified a tiny lesion in the navicular fossa, which was biopsied and confirmed to be a squamous cell carcinoma. The patient then underwent phallus preserving surgery, including distal urethrectomy with bilateral inguinal lymph node dissections. The final stage was pT1N1M0, and adjuvant chemotherapy was started. The distal urethrectomy involved the surgical creation of a hypospadic meatus in the midshaft of the penis. Normal voiding and sexual function were preserved.

Conclusions: Urethral cancer is a rare malignancy and clinicians should bear in mind that early diagnosis of this disease can be very difficult depending on the anatomical location of the tumour. Treatment currently favours penispreserving surgery.
\end{abstract}

Keywords: Urethral carcinoma, Penis-preserving surgery, Multi-modal therapy, Hypospadic neomeatus

\section{Background}

Primary Urethral Carcinoma (PUC) is a rare malignancy, comprising $<1 \%$ of all malignancies in male patients. Early reports have identified tumour stage and site as the predominant prognostic factor [1] with higher stage tumours having a worse prognosis as well as those arising in the posterior urethra as compared to the anterior urethra [2]. Urethral carcinoma has historically been managed by partial or radical penectomy for distal tumours or total penectomy with cystoprostatectomy for proximal tumours [3]. However, neoplasms of the anterior urethra can be managed successfully with conservative surgical options [2]. In sharp contrast, the successful

\footnotetext{
*Correspondence: emilywalsh@rcsi.ie

${ }^{1}$ Department of Urology, Department of Surgery, University Hospital Waterford, Waterford, Ireland
}

Full list of author information is available at the end of the article management of posterior urethral cancers can prove to be more difficult.

PUCs tend to display a greater variety in histological subtypes, based on the anatomical location and gender. The lining of the urethra alters depending on the anatomical location. This accounts for the variation in tumour subtype. The prostatic urethra is composed of transitional epithelium. In the membranous and spongy urethra there is stratified columnar epithelium. The most common malignant subtypes are squamous cell carcinoma (SCCs) or transitional cell carcinomas (TCCs), with incidences varying in the literature. SCC tends to account for approximately $25 \%$ of male urethral cancers and $20 \%$ of female urethral cancers [4]. Adenocarcinoma may also occur [5]. SCCs are commonly found in the penile urethra rather than in the bulbar and membranous urethra $[6,7]$ original author(s) and the source, provide a link to the Creative Commons licence, and indicate if changes were made. The images or other third party material in this article are included in the article's Creative Commons licence, unless indicated otherwise in a credit line to the material. If material is not included in the article's Creative Commons licence and your intended use is not permitted by statutory regulation or exceeds the permitted use, you will need to obtain permission directly from the copyright holder. To view a copy of this licence, visit http://creativecommons.org/licenses/by/4.0/. The Creative Commons Public Domain Dedication waiver (http://creativeco mmons.org/publicdomain/zero/1.0/) applies to the data made available in this article, unless otherwise stated in a credit line to the data. 
The regional spread determines the natural history of urethral cancer at the time of diagnosis. The lymphatic drainage of the anterior urethra is to the superficial and deep inguinal lymph nodes. The main drainage of the posterior urethra is to the pelvic lymph nodes. Approximately one-third of patients may have regional lymph node involvement at the time of presentation [8]. In urethral cancer enlarged lymph nodes are generally indicative of metastatic disease [9]. Although distant metastasis at the time of presentation is rare, this patient presented with a metastatic node left groin. Furthermore, preoperative diagnosis of urethral cancer was difficult in this case due to its non-specific presentation.

\section{Case presentation}

An 80-year-old Caucasian male initially presented to a peripheral unit with a lymph node mass in left groin. Ultrasound revealed a large pathological lymph node measuring $5 \mathrm{~cm}$ in length. A lymph node biopsy was performed and revealed metastatic squamous cell carcinoma with immunohistochemistry findings suspicious for human papillomavirus type 16 specific staining (Fig. 1).

Computed tomographic (CT) scans of the chest, abdomen and pelvis showed bilateral inguinal lymph node more marked on the left and indeterminate subcentimeter left pulmonary nodules. No primary neoplastic process was detected. We performed a 18F-fludeoxyglucose positron emission tomography/computed tomography (18F-FDG PET/CT) which revealed a Standardised Uptake Value (SUV) of 11 on left inguinal mass and low grade uptake overlying lower sacrum (Fig. 2).

As no primary lesion had been detected and there were histological findings suspicious for a metastatic

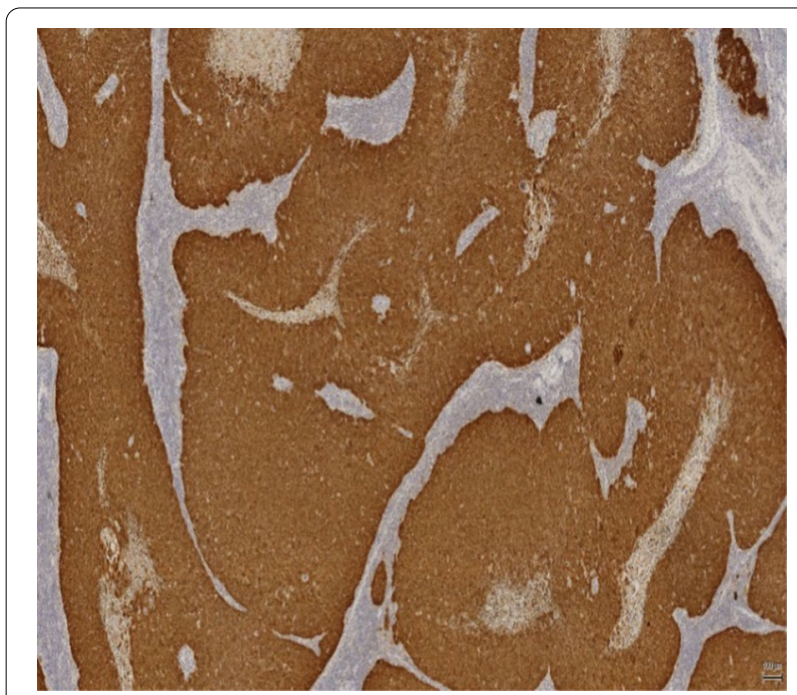

Fig. 1 p16 positivity in lymph node metastasis

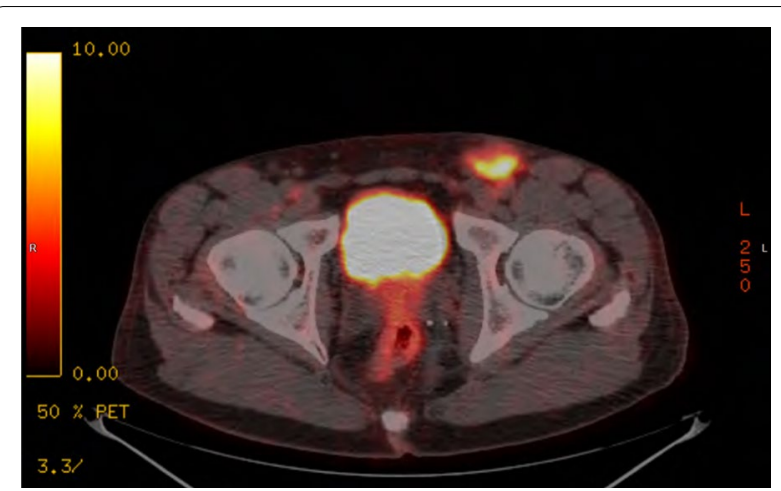

Fig. 2 Positron emission tomography scan showing

${ }^{18} \mathrm{~F}$-fluorodeoxyglucose uptake in left inguinal lymph node, which was confirmed to have metastatic squamous cell carcinomas

squamous cell cancer, magnetic resonance imaging (MRI) of the penis was performed to identify a possible penile cancer primary. A T2 weighted MRI (coronal image) after intracavernosal prostaglandin demonstrated a large lymph node in left groin, a normal urethra and corpora cavernosa (see Fig. 3a). MRI after intracavernosal prostaglandin demonstrated normal corpora cavernosa and normal urethra (see Fig. 3b). The use of intracavernosal prostaglandins with penile MRI imaging can help in the detection of penile cancers [8]. No such lesion was identified this patient.

Proctoscopy and colonoscopy were performed to assess for an anal SCC and were negative for disease. Flexible cystoscopy was also performed which revealed a small nonspecific lesion within the navicular fossa of the distal urethra and was biopsied (see Fig. 4).

Distal urethrectomy with bilateral inguinal lymph node dissection was performed with radical inguinal lymphadenectomy performed on the affected side and a superficial modified approach used on the contralateral groin.

A surgically created hypospadic neomeatus was created within the penile shaft (see Fig. 5). 11 nodes were removed and metastatic squamous cell carcinoma was present in one of the lymph nodes measuring $4.5 \mathrm{~cm}$ in length. There was no extracapsular extension. On the right side, 9 lymph nodes were removed with no evidence of neoplasia. Histopathological analysis of the distal urethrectomy specimen confirmed an invasive squamous cell carcinoma of the distal urethra (see Figs. 6 and 7). This was a Human papillomavirus (HPV) related basaloid lesion with an invasive component of $4.5 \mathrm{~mm}$ in size. As per the TNM staging, this staged the disease as a T1N1Mx [4]. The patient has been referred for adjuvant treatment consisting of carboplatin (Area 

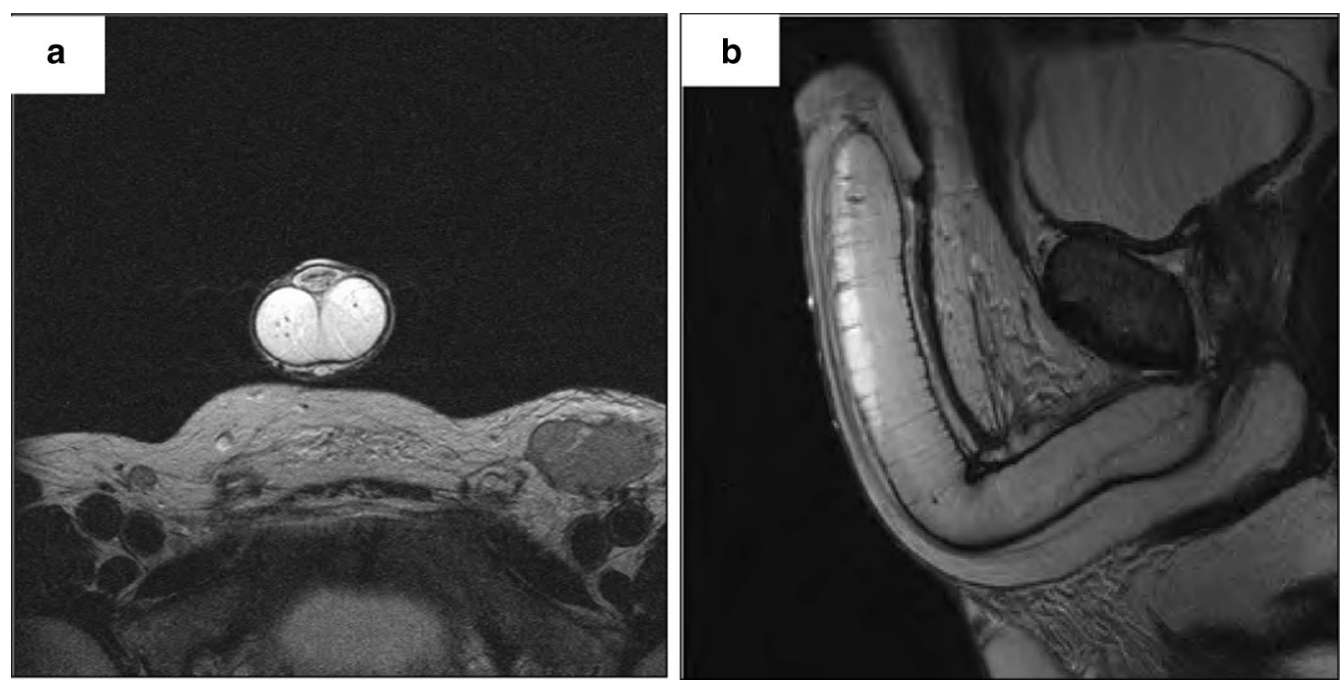

Fig. 3 a Large lymph node in left groin with normal urethra and corpora cavernosa. b Normal corpora cavernosa and normal urethra. Tumour was not evident of the scan

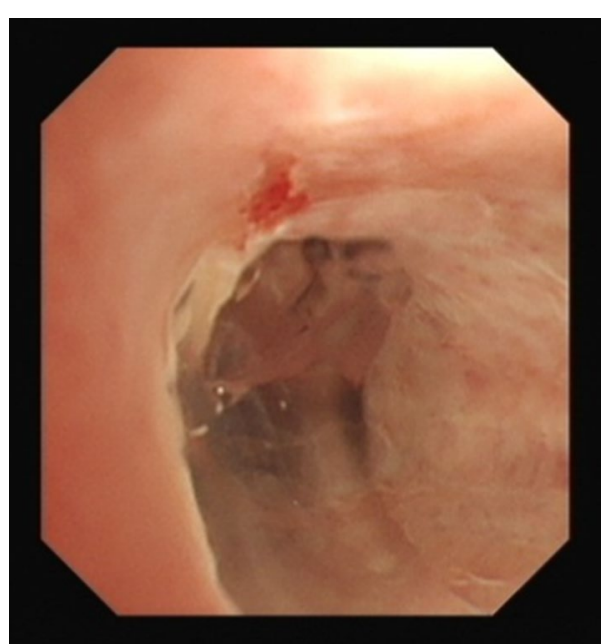

Fig. 4 Endoscopic image demonstrating squamous cell carcinomas lesion in the navicular fossa

Under the Curve $(\mathrm{AUC})=5)$ and paclitaxel $(175 \mathrm{mg} /$ $\mathrm{m}^{2}$ ) for four cycles.

\section{Discussion and conclusion}

PUC in males often presents with urinary obstructive symptom. One study [10] reported obstructive and irritative symptoms in $43 \%$ and $20 \%$ of men, respectively. Haematuria, abscess or discharge prior to diagnosis [1] have also been reported as well as a previous history of urethral stricture disease or obstructive symptoms [11-13]. The development of PUC has also been associated with previous urethral surgery and radiotherapy. However,

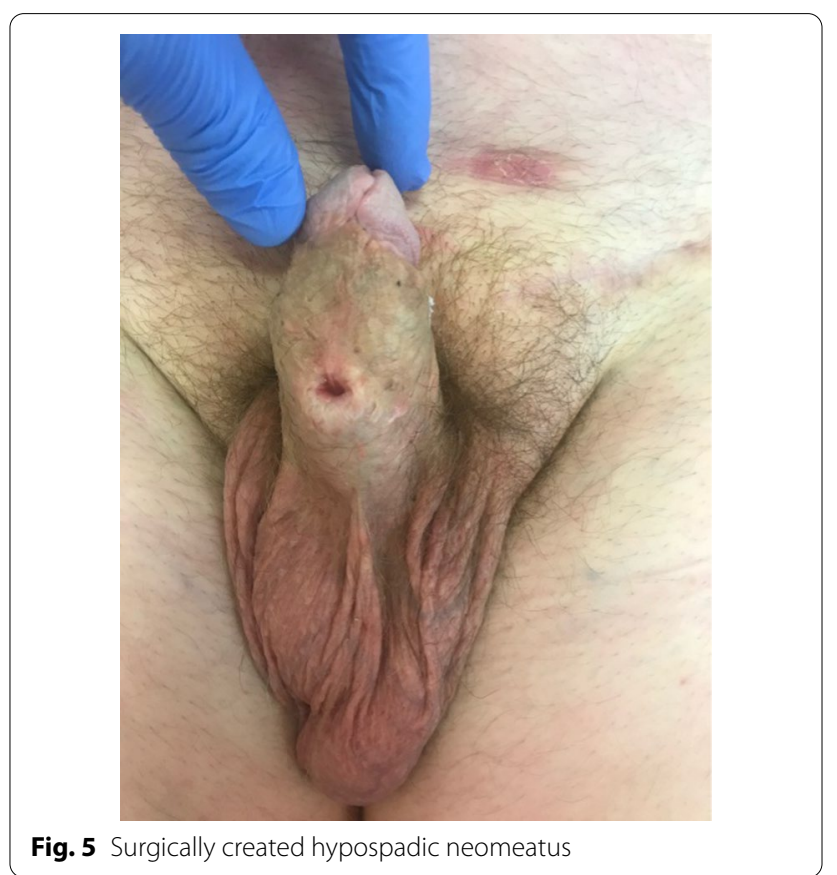

in the case presented here, the patient had no reported symptoms and no risk factors, which made the diagnosis of urethral cancer more difficult. Considering the nonspecific presentation of urethral cancer, a high index of suspicion is required for diagnosis.

Due to the low incidence of PUC there is sparse data available on the pathogenesis of urethral cancer. It is believed that chronic inflammation and irritation of the urethra may play a role in the development of urethral cancer. The rapid turnover of the urethral mucosal 


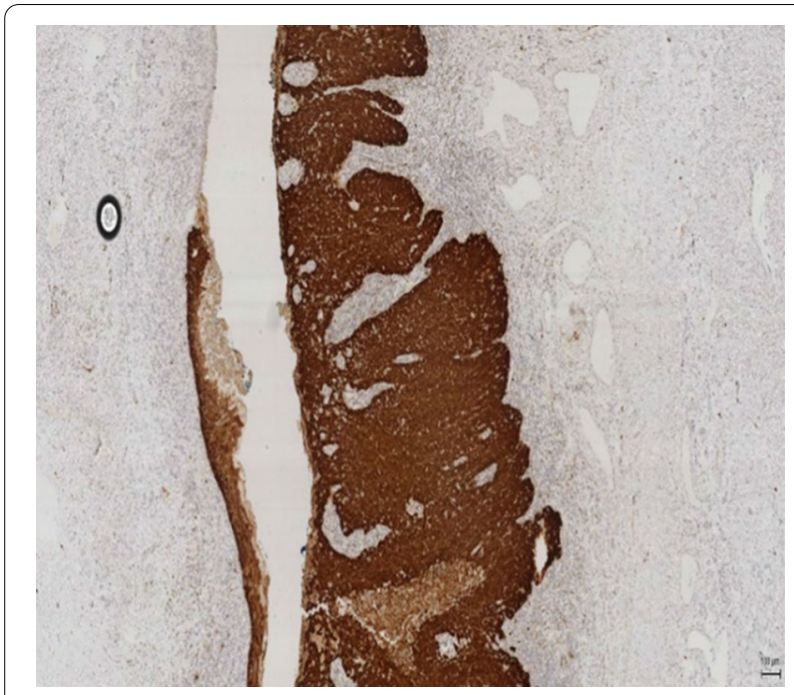

Fig. 6 p16 positivity in squamous cell carcinomas

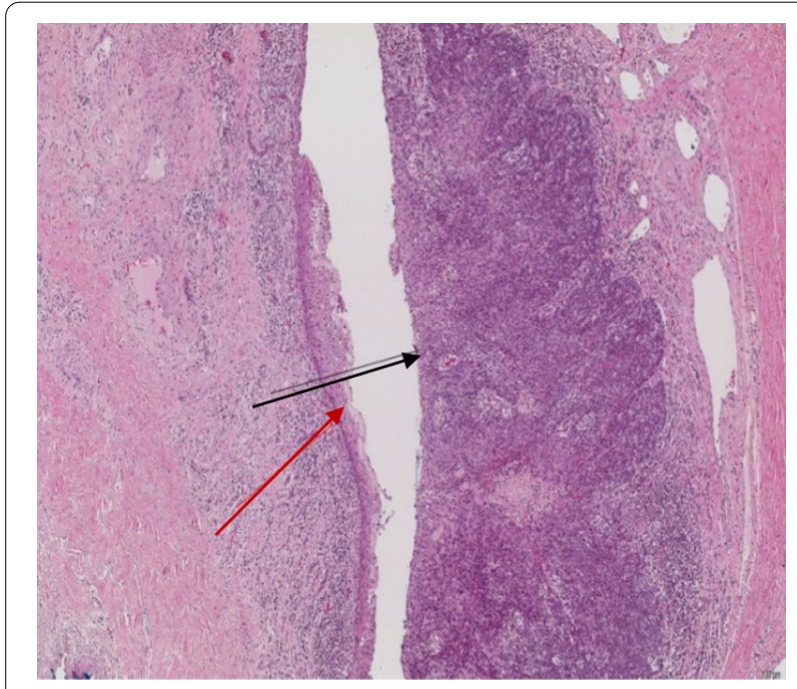

Fig. 7 Normal (red arrow) and squamous cell carcinomas (black arrow)

cells also predisposes to the development of dysplasia and neoplasia. However, the exact pathophysiological mechanisms involved in the development of urethral cancer have not been elucidated.

Approximately a third of urethral cancer cases are due to HPV [14]. The distal urethra has been shown to be a reservoir of HPV infection [15]. The HPV viral proteins E6 and E7 inhibit the actions of p53 and Rb in penile caner [16]. In virally-induced SCC, there is an altered expression of the genes involved in invasion, angiogenesis and metastasis, such as ras, myc and telomerase $[17,18]$. In the case presented here, the histopathology report showed an HPV related basaloid

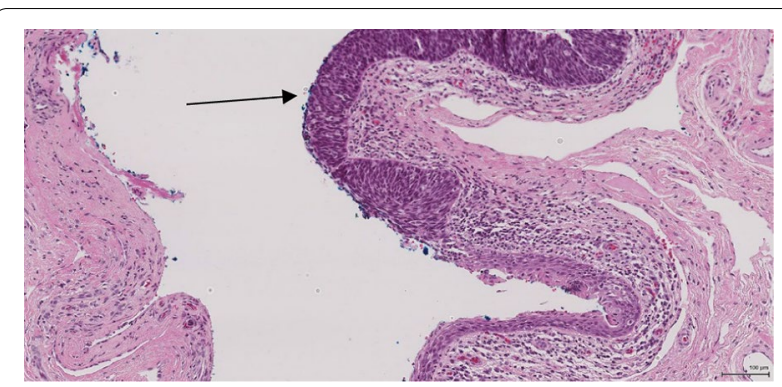

Fig. 8 Histopathological picture of urethra with a HPV related basaloid PelN (arrow) and normal epithelial

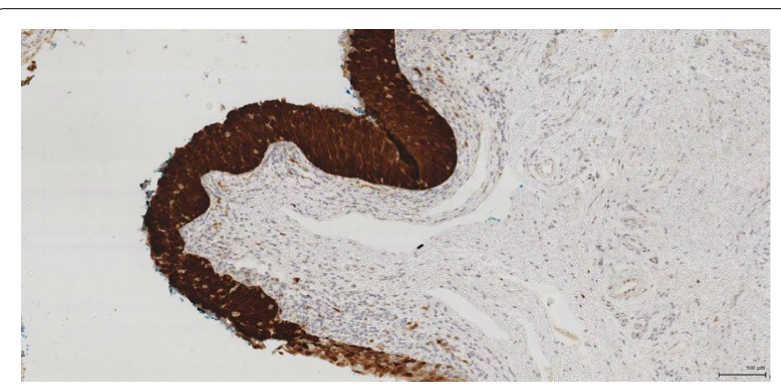

Fig. 9 Histopathological picture of penile intraepithelial neoplasia (PelN) with p16 positivity (brown stain) in the urethral specimen

lesion in the navicular fossa as well as an SCC in the left groin ( see Figs. 1, 6, 7, 8, and 9). This demonstrates that HPV was the causative agent leading to the development of urethral cancer.

The treatment of urethral carcinoma is not uniform. Two groups of patients with different survival characteristic are recognised. The first group is those with proximal disease. The survival rate is poorer in this group even with a multimodal therapy involving surgery, chemotherapy, and radiotherapy and often presents with advanced disease [6]. The second group is those with distal tumours. These tend to have a better outcome as local surgical control can be achieved [6].

Urethral carcinoma has historically been managed by partial or radical penectomy for distal tumours or total penectomy with cystoprostatectomy for proximal tumours. The management of urethral cancer has been similar to that of penile cancer whereby surgical excision of the primary lesion with a $2 \mathrm{~cm}$ clear margin has been encouraged. However, one study showed that $<5 \mathrm{~mm}$ resection margins with penis preserving surgery with iliac/inguinal lymphadectomy for clinical suspected nodal disease in men with pT1-3NO-2 anterior urethral cancer resulted in no local recurrence [6]. Thus, phallus preservation surgery can be considered in certain patients. We followed a similar 
treatment modality for our patient with surgery involving distal urethrectomy with bilateral inguinal lymph node dissections accompanied by chemotherapy. Negative margins were achieved and there has been no local recurrence to date. The outcome was oncologically satisfactory and the patient does not report any complaints about urinary symptoms or erectile dysfunction. Therefore, penis preserving surgeries could be used safely and decrease the psychological burden associated with total or partial penectomy as well as maintaining quality of life and maintaining functional outcome.

Surveillance protocols for patients who have had treatment for urethral cancer has not been established. Tailoring the surveillance regimens based on the patients individual risk factors has been advised [19]. A more extensive follow-up would be required in patients who underwent penis preserving surgery [19]. This includes cytology, flexible cystoscopy and cross sectional imaging. However, evidence that urine cytology may be useful remains to be determined [20]. Our patient's follow-up will be determined based on response to adjuvant chemotherapy.

We report on the surgical management of a patient with a distal urethral primary carcinoma presenting with local node involvement which was managed successfully with phallus preserving surgery and inguinal node dissection. Primary urethral cancer is a rare urological malignancy that can prove challenging to diagnose and is usually found in the older population. The management of urethral cancer can also be difficult and the more important clinical prognostic factors for male urethral cancer are clinical stage and the anatomical location of the tumour. Treatment currently favours penis-preserving surgery for distal disease, though proximal urethral cancers still require radical resections. The 5 year overall survival is approximately $50 \%$.

\section{Abbreviations \\ PUC: Primary urethral carcinoma; CT: Computed tomography; HPV: Human papilloma virus; SCCs: Squamous cell carcinomas; TCCs: Transitional cell carcinomas.}

\section{Acknowledgements}

Not applicable.

\section{Authors' contributions}

IC and PD diagnosed, treated and maintained follow up of the patient. IC photographed the patient and performed consultations with the pathology department. All authors wrote, edited the final manuscript. All authors read and approved the final manuscript.

\section{Funding}

Not applicable.

\section{Availability of data and materials} Not applicable.
Ethics approval and consent to participate Not applicable.

\section{Consent for publication}

Written informed consent was obtained from the patient for publication of this case report and accompanying images. A copy of the written consent is available for review by the Editor-in-Chief of this journal.

\section{Competing interests}

The authors declare that they have no competing interests.

\section{Author details}

${ }^{1}$ Department of Urology, Department of Surgery, University Hospital Waterford, Waterford, Ireland. ${ }^{2}$ Department of Histopathology, University Hospital Waterford, Waterford, Ireland.

Received: 2 October 2019 Accepted: 11 October 2020

Published online: 19 February 2021

\section{References}

1. Ray B, Canto AR, Whitmore WF Jr. Experience with primary carcinoma of the male urethra. J Urol. 1977;117:591-4.

2. Anderson KA, McAninch JW. Primary squamous cell carcinoma of anterior male urethra. Urology. 1984;23:134-40.

3. Zeidman EJ, Desmond P, Thompson IM. Surgical treatment of carcinoma of the male urethra. Urol Clin N Am. 1992;19:359-72.

4. Gakis G, Witjes JA, Bruins M, Compérat E, Cowan NC, Hernàndez V, et al. EAU guidelines primary urethral carcinoma. 2018. https://uroweb.org/ wp-content/uploads/EAU-Primary-Urethral-Carcinoma-Guidelines-2018V 2.pdf. Accessed 20 Feb 2019.

5. Dayyani F, Hoffman K, Eifel P, Guo C, Vikram R, Pagliaro LC, et al. Management of advanced primary urethral carcinomas. BJU Int. 2014;1 14:25-31.

6. Smith Y, Hadway P, Ahmed S, Perry MJ, Corbishley CM, Watkin NA. Penile-preserving surgery for male distal urethral carcinoma. BJU Int. 2007;100:82-7.

7. Oberfield RA, Zinman LN, Leibenhaut M, Girshovich L, Silverman ML. Management of invasive squamous cell carcinoma of the bulbomembranous male urethra with co-ordinated chemo-radiotherapy and genital preservation. Br J Urol. 1996;78:573-8.

8. Heyns CF, Mendoza-Valdes A, Pompeo AC. Diagnosis and staging of penile cancer. Urology. 2010;76:S15-23.

9. Dayyani F, Pettaway CA, Kamat AM, Munsell MF, Sircar K, Pagliaro LC. Retrospective analysis of survival outcomes and the role of cisplatin-based chemotherapy in patients with urethral carcinomas referred to medical oncologists. Urol Oncol. 2013;31:1171-7.

10. Dalbagni G, Zhang ZF, Lacombe L, Herr HW. Male urethral carcinoma: analysis of treatment outcome. Urology. 1999;53:1126-32.

11. Dinney CP, Johnson DE, Swanson DA, Babaian RJ, von Eschenbach AC. Therapy and prognosis for male anterior urethral carcinoma: an update. Urology. 1994;43:506-14.

12. Mohan H, Bal A, Punia RP, Bawa AS. Squamous cell carcinoma of the prostate. Int J Urol. 2003;10:114-6.

13. Colapinto V, Evans DH. Primary carcinoma of the male urethra developing after urethroplasty for stricture. J Urol. 1977;118:581-4.

14. Wiener JS, Liu ET, Walther PJ. Oncogenic human papillomavirus type 16 is associated with squamous cell cancer of the male urethra. Cancer Res. 1992:52:5018-23.

15. Grussendorf-Conen El, Deutz FJ, de Villiers EM. Detection of human papillomavirus-6 in primary carcinoma of the urethra in men. Cancer. 1987:60:1832-5.

16. Ferreux E, Lont AP, Horenblas S, Gallee MP, Raaphorst FM, von Knebel $\mathrm{DM}$, et al. Evidence for at least three alternative mechanisms targeting the p16INK4A/cyclin D/Rb pathway in penile carcinoma, one of which is mediated by high-risk human papillomavirus. J Pathol. 2003;201:109-18.

17. Couturier J, Sastre-Garau X, Schneider-Maunoury S, Labib A, Orth G. Integration of papillomavirus DNA near myc genes in genital carcinomas and its consequences for proto-oncogene expression. J Virol. 1991;65:4534-8. 
18. Alves G, Fiedler W, Guenther E, Nascimento P, Campos MM, Ornellas AA. Determination of telomerase activity in squamous cell carcinoma of the penis. Int J Oncol. 2001;18:67-70.

19. Gakis G, Witjes JA, Comperat E, Cowan NC, De Santis M, Lebret T, et al. EAU guidelines on primary urethral carcinoma. Eur Urol. 2013;64:823-30.

20. Mandler JI, Pool TL. Primary carcinoma of the male urethra. J Urol. 1966;96:67-72.

\section{Publisher's Note}

Springer Nature remains neutral with regard to jurisdictional claims in published maps and institutional affiliations.
Ready to submit your research? Choose BMC and benefit from:

- fast, convenient online submission

- thorough peer review by experienced researchers in your field

- rapid publication on acceptance

- support for research data, including large and complex data types

- gold Open Access which fosters wider collaboration and increased citations

- maximum visibility for your research: over 100M website views per year

At BMC, research is always in progress.

Learn more biomedcentral.com/submissions 